\title{
DNA 折纸术的研究进展
}

\author{
石党委 ${ }^{(12)}$ ，王振刚 ${ }^{2}$, 徐景坤 ${ }^{(1 *}$, 丁宝全 ${ }^{2 *}$ \\ (1) 江西科技师范大学江西省有机功能分子重点实验室, 南昌 330013; \\ (2) 国家纳米科学中心, 北京 100190 \\ * 联系人, E-mail: xujingkun@ @tsinghua.org.cn; dingbq@ nanoctr.cn \\ 2012-11-25 收稿, 2013-01-23 接受, 2013-05-06 网络版发表 \\ 国家重点基础研究发展计划(2012CB934000)、中国科学院“百人计划”和国家自然科学基金(21173059, 91127021, 51073074)资助
}

\begin{abstract}
摘要 DNA 折纸术是近年来提出的一种新颖的 DNA 自组装方法, 是 DNA 纳米技术和 DNA 自 组装领域的重大研究进展之一。与传统的 DNA 自组装技术不同, DNA 折纸术通过一条长的环 状单链DNA 与一系列预设计的短链DNA片段碱基互补配对, 构造出高度复杂的二维纳米图案 和三维纳米结构. 与传统纳米自组装方法相比, DNA 折纸术构造的二维、三维纳米结构, 具有 更佳的精细程度和可控性, 而且其实验条件要求低, 操作简单, 效率高. 将二维或三维 DNA 折 纸纳米结构作为模板, 与功能纳米粒子进行组装, 能够得到具有特殊性能的纳米器件, 因此 DNA 折纸术在纳米领域具有巨大的潜在应用价值. 本文介绍了 DNA 折纸术在功能复合结构组 装方面的研究进展与 DNA 折纸术的展望.
\end{abstract}

关键词

DNA 自组装 DNA 折纸术 纳米器件 模板 可控制 高效
当物质的尺寸达到纳米尺度时, 光学和物理学 等性质会明显异于宏观物质, 因此纳米尺度材料引 起了众多化学家、材料学家以及生物学家的关注. 目 前, 组装纳米材料的方法主要有两种: 自上而下 (top-

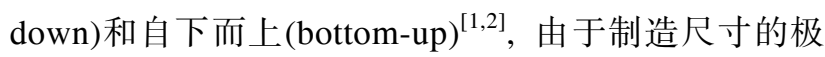
限，自上而下的制作方法面临许多障碍与挑战. 自下 而上的自组装方法是采用分子尺度材料构建纳米功 能尺度器件的制备方法. 基于自下而上的分子组装 策略更容易制备复杂精细的纳米器件. 分子自组装 是指分子在热力学平衡条件下, 通过分子间弱相互 作用力的协同作用自发形成的结构稳定、复杂有序且 具有某些特定功能的分子聚集体或超分子结构的过 程. DNA 自组装 ${ }^{[3,4]}$ 是分子自组装研究领域的热点. DNA 自组装是在热力学驱动下, 两条互补的单链 DNA 分子自发杂交的动力学过程. 在杂交过程中, DNA 双链通过氢键、范德华力和静电力相互作用, 严 格遵守 Watson-Crick 碱基互补配对原则. 2006 年, Rothemund $^{[5]}$ 首次提出了一种全新的 DNA 自组装方
法—DNA 折纸术(DNA origami), 并以封面文章的 形式在 Nature 杂志上发表. DNA 折纸术 ${ }^{[6-9]}$ 是利用 DNA 分子的特殊结构和碱基互补配对的规则, 将天 然 DNA 长链的特定区域进行折叠, 并用短链加以固 定，构造出预期的结构. 与传统的自上而下组装方法 相比, DNA 折纸术的明显优势在于其不仅能够在纳 米尺度上对 DNA 链进行精确的组装与排列, 得到 更加复杂精细的结构, 而且实验条件简单、操作简 便、组装高效. 利用 DNA 折纸术得到的结构作为模 板组装功能纳米材料或分子, 能够获得光学、电磁学

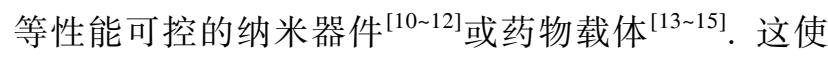
得 DNA 折纸术在纳米领域具有非常巨大的潜在应用 价值. 2006 2012 年间, 研究人员利用折纸术成功构 造出多种复杂精细的二维和三维结构, 推动了纳米 器件领域的发展. 本文从 DNA 折纸术的发展历程及 其在纳米器件的制备和潜在应用等方面进行介绍, 并展望 DNA 折纸术在纳米器件研究领域的研究 方向.

引用格式: 石党委, 王振刚, 徐景坤, 等. DNA 折纸术的研究进展. 科学通报, 2013, 58: 2367-2376 Shi D W, Wang Z G, Xu J K, et al. Recent progress in DNA origami (in Chinese). Chin Sci Bull (Chin Ver), 2013, 58: 2367-2376, doi: 10.1360/ 972012-1626 


\section{DNA 折纸术的研究进展}

\section{1 二维 DNA 折纸术的研究进展}

20 世纪 80 年代, Seeman ${ }^{[16]}$ 首次提出 DNA 能产 生稳定的连接结构, 通过碱基互补配对可精确组装 复杂多维空间对象, 并称之为结构 DNA 纳米技术 (structural DNA nanotechnology). 研究人员随后不断 构造出不同的模块, 如 DX(double-crossover)模 块 ${ }^{[17 ~ 21]} 、 \mathrm{TX}$ (triple-crossover) 模块 ${ }^{[22]}$ 、十字模块 ${ }^{[23]}$ 和 对称模块 ${ }^{[24]}$, 并用模块组装得到了各式各样的图形 结构 (二维阵列、方形网格、多面体等 $)^{[25]}$. 但模块法 组装是通过小结构单元的碱基互补配对拼接成较大 的图形结构, 其尺寸和形状难以精确控制. 2006 年, Rothemund ${ }^{[5]}$ 提出了一种全新的 DNA 自组装的方法 —DNA 折纸术(DNA origami). 在折纸术中, 首先 设计组装所需的订书钉链, 使脚手架链 DNA(噬菌体 的环状单链 DNA, M13mp18, 7249bp)能够在特定位 置通过碱基互补配对进行折叠连接, 得到几何模型, 如图 1 所示. 在组装时, 将脚手架链 M13 DNA 和过 量的订书钉链进行混合, 将溶液温度从 $95^{\circ} \mathrm{C}$ 缓慢降 低到 $20^{\circ} \mathrm{C}$, 即可得到预期的折纸纳米结构. 通过 DNA 折纸术, Rothemund 得到了三角形、方形、矩形、 五角星、笑脸等精细复杂的二维结构(图 2). 得到的

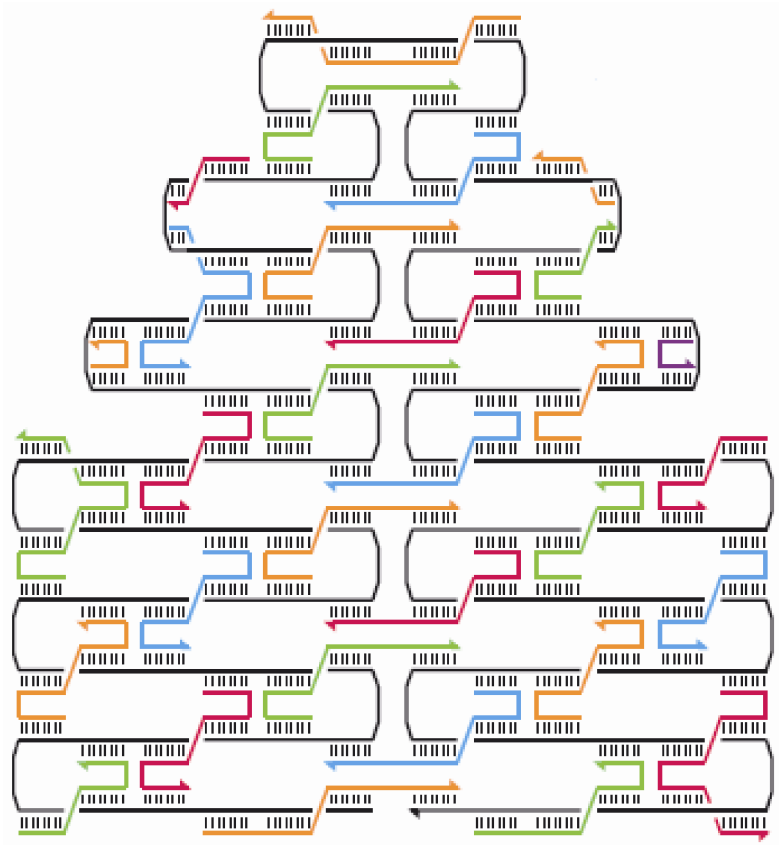

图 1 折纸术示意图 ${ }^{[5]}$

黑色长链为脚手架链, 彩色短链为订书钉链
二维折纸术结构尺寸通常在 $100 \mathrm{~nm}$ 左右, 空间分辨 率达到 $6 \mathrm{~nm}$, 比通过模块 DNA 自组装得到的结构更 为精密. Rothemund 的研究为实现纳米结构的精确组 装奠定了基础, 随后更加复杂多样的纳米结构 ${ }^{[26,27]}$ 不断被设计并组装出来, 为纳米器件的深入研究提 供更为精密的模板.

\section{2 三维 DNA 折纸术的研究进展}

2007 年, Douglas 等人 ${ }^{[28]}$ 采用 DNA 折纸术的方 法, 通过特定的位点设计, 将 M13 作为脚手架链折 叠成长 $410 \mathrm{~nm}$ 的六螺旋纳米管. 这是研究人员第一 次使用 DNA 折纸术的方法制造出三维结构, 它揭开 了三维纳米 DNA 结构组装的序幕. 随后, 研究人员 设计并得到了许多复杂精美的三维 DNA 自组装结构. 2009 年, Douglas 等人 ${ }^{[29]}$ 采用 DNA 折纸术得到了方 块、螺母、桥架等 5 种结构复杂的三维结构. 他们首 先利用 DNA 折纸术自组装成蜂窝形状的三维结构单 元, 再通过分级组装实现多个折纸术三维结构的连 接, 得到具有更大尺寸、更为复杂的三维 DNA 折纸 结构. 同年, Dietz 等人 ${ }^{[30]}$ 通过设计、组装得到了带有 弧线的立体 DNA 纳米结构(图 3). 研究人员在设计时 通过添加和删减部分碱基对实现 DNA 束(DNA bundles)的扭曲或弯曲, 组装得到了带有一定曲度的三 维结构.

2009 年, Andersen 等人 ${ }^{[31]}$ 通过合理的设计, 利用 DNA 自组装得到了三维 DNA 纳米盒子 $(42 \mathrm{~nm} \times 36$ $\mathrm{nm} \times 36 \mathrm{~nm}$ ), 如图 4 所示. 纳米尺寸的盒子被设计具 有可以打开的盖子; 在 DNA“钥匙”存在的情况下, 盒子的盖子会被打开. 这种纳米尺寸的三维 DNA 盒 子可被应用于检测领域，只有匹配的 DNA“钥匙”才 可打开盒子, 可被用来检测特定的序列. 此外, 盒子 内部空间还有可能作为载体容纳核糖体或病毒, 在 合适的条件时(如 DNA“钥匙”)释放所包含的物质.

2011年, Han等人 ${ }^{[32]}$ 利用DNA折纸术设计并组装 出多种具有弧度的三维封闭的DNA纳米结构, 如圆 球、椭圆球和花瓶等(图5). 他们描述了一种新的DNA 折纸策略, 即堆叠不同半径的DNA链形成的环形物, 形成基本的三维形状，随后嵌人“交叉点”使环毗邻的 DNA环结合为一体, 形成预期设计的三维纳米结构. $\mathrm{Han}$ 等人的研究, 极大推动了立体曲面的三维DNA纳 米结构的制备研究. 三维DNA纳米结构的空腔可用于 盛载一些药物分子 ${ }^{[33 \sim 35]}$, 实现疾病的靶向治疗. 

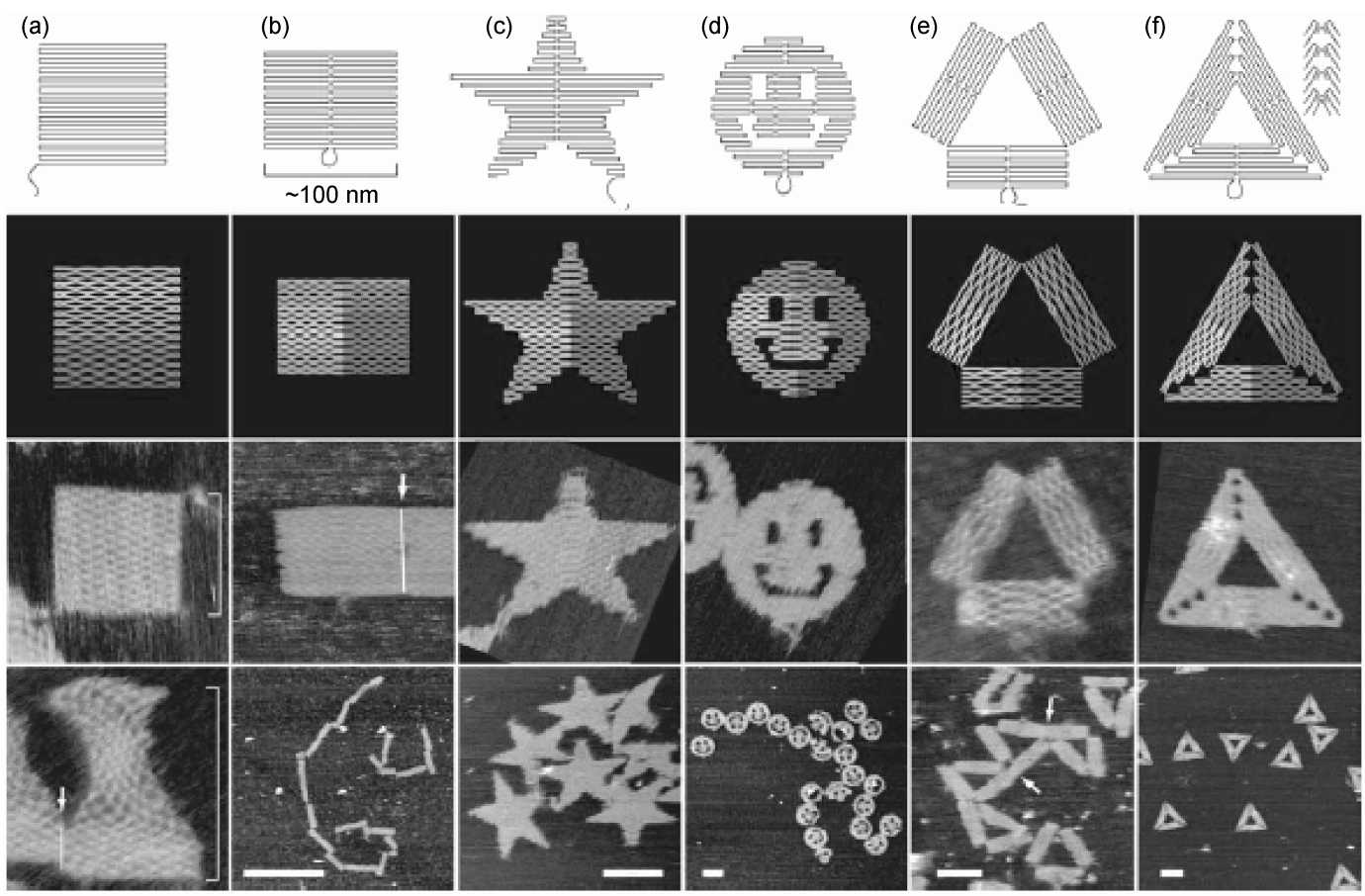

图 26 种通过 DNA 折纸术得到的二维结构图形 ${ }^{[5]}$

前两行从左至右依次是: (a) 方形; (b) 矩形; (c) 五角星; (d) 笑脸; (e) 矩形围成的三角形区域; (f) 三角形. 后两行是对应二维结构在 AFM 下观测到的图像(标尺示 $100 \mathrm{~nm}$ )

(a)

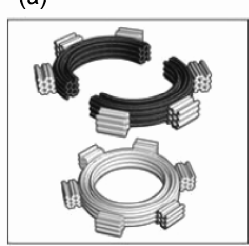

(b)

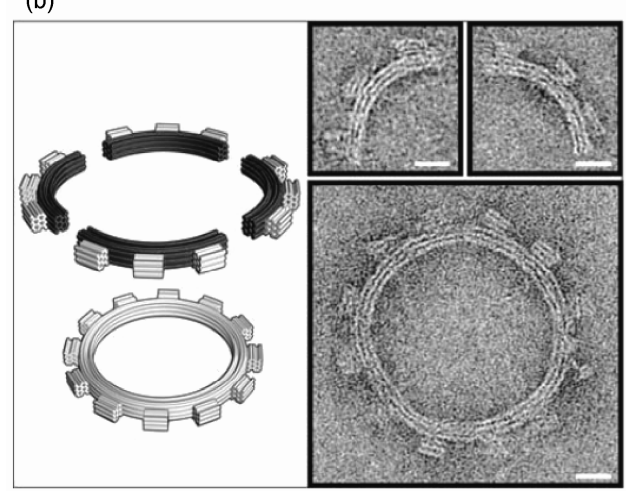

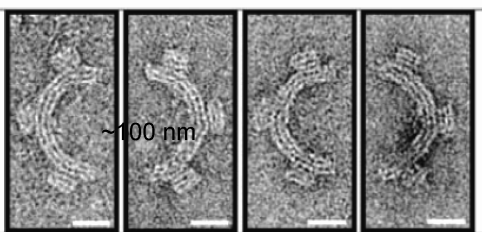

(c)

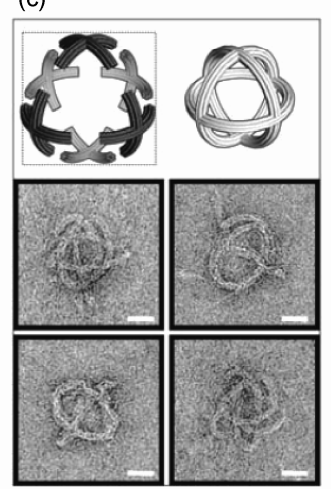

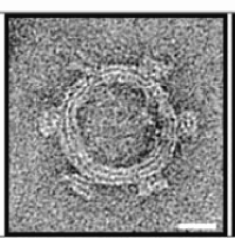

(d)

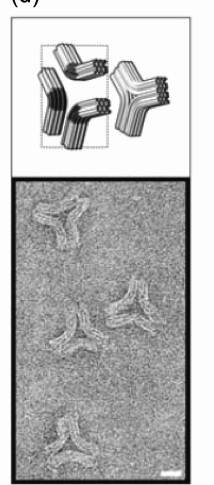

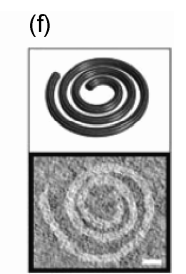

(e)

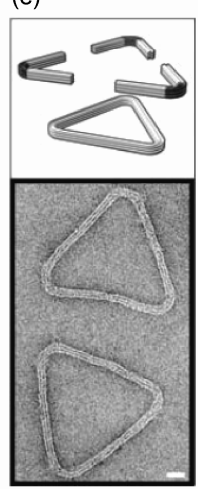

图 3 多种复杂的非线性弯曲的折纸术结构

(a) 半径 $25 \mathrm{~nm}$ 的折纸术齿轮结构及其 TEM 照片; (b) 半径 $50 \mathrm{~nm}$ 的折纸术齿轮结构及其 TEM 照片; (c) $50 \mathrm{~nm}$ 宽的球形线框囊状结构 及其 TEM 照片; (d) 内凹的三角形折纸术结构及其 TEM 照片; (e) 外凸的三角形折纸术结构及其 TEM 照片; (f) 螺旋 DNA 折纸术结构 及其 TEM 照片 ${ }^{[30]}$ 
(a)
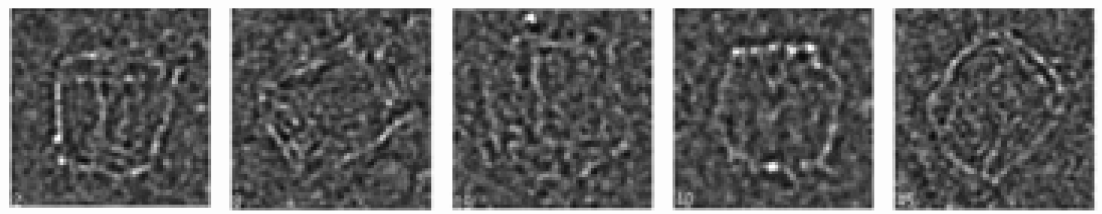

(b)
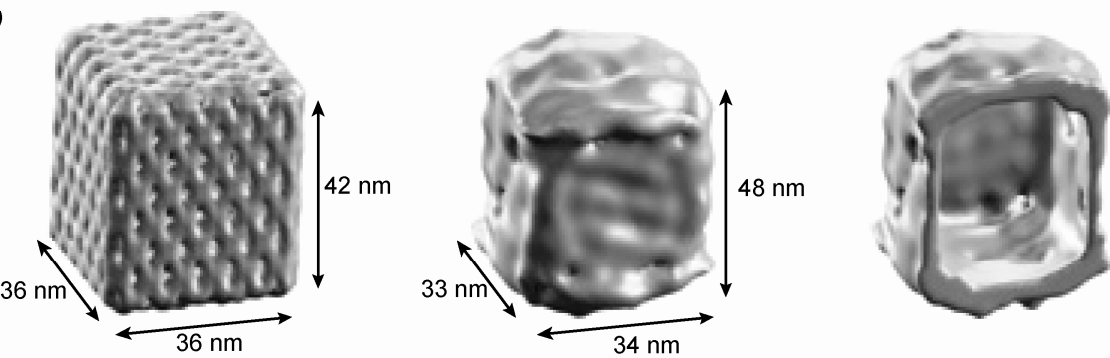

(c)

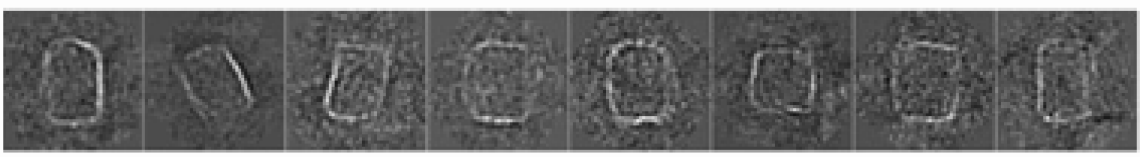

(d)

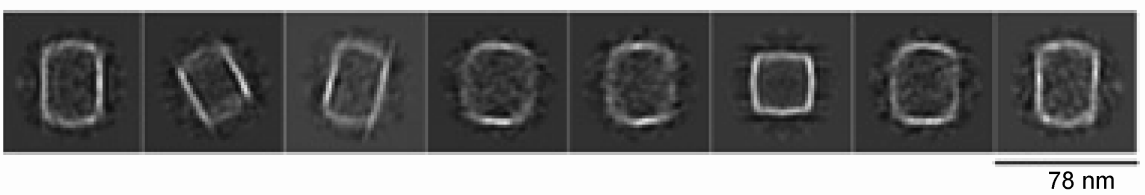

图 4 盒状折纸术结构

（a）单个盒状折纸术结构的冷场电子显微镜照片; (b) 左侧是盒状结构的理论模型，中间是盒状结构的冷场表征，右侧是内部结构的 冷场图; (c), (d) 盒状折纸术的平均尺寸 ${ }^{[31]}$
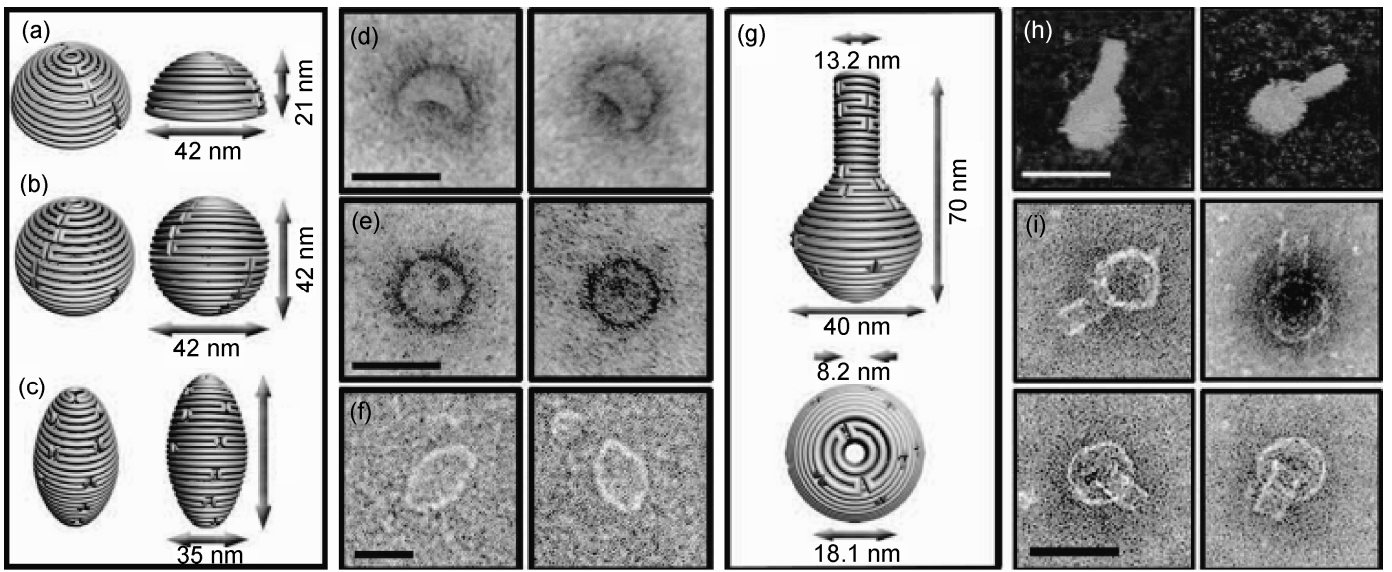

图 5 复杂的环形三维纳米结构 ${ }^{[32]}$

(a) 半球的图解; (b) 球体的图解; (c) 椭球形的图解; (d) 半球的 TEM 暗场照片; (e) 球体的 TEM 暗场照片; (f) 籿球形的 TEM 明场像; (d) (f)的图片尺寸大小为 $50 \mathrm{~nm}$. (g) 细颈花瓶型三维结构示意图; (h) 细颈花瓶的 AFM 照片, 图片尺寸大小 $75 \mathrm{~nm}$; (i) 细颈花瓶的 TEM 照片，图片尺寸大小为 $50 \mathrm{~nm}$

\section{DNA 折纸术的应用}

随着社会的发展以及科学技术的不断进步，自 上而下方法得到的微型器件难以满足人们对精细复
杂程度的需要,而自下而上的 DNA 自组装方法显现 出巨大的优势. DNA 折纸术作为 DNA 自组装方法的 升华，其应用前景非常广阔. 以 DNA 折纸术得到的 纳米结构作为载体, 精确地组装其他功能纳米材料 


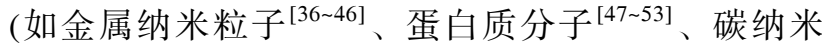
管 ${ }^{[54]}$ 、量子点 ${ }^{[55 ~ 57]}$ 等), 可得到具有特殊功能的纳米 器件或药物载体 ${ }^{[49]}$. 例如, 以 DNA 折纸术结构作为 模板，组装贵金属纳米粒子，通过精确控制纳米粒子 的相对空间排列, 可改变纳米粒子的光电性质, 在纳 米光电子学、细胞分子生物物理学、能量转移和疾病 检测与治疗等方面具有巨大的潜在应用价值. 目前 DNA 折纸术在纳米器件上的探索主要围绕以下三个 方面开展。

\section{1 制造纳米尺度的 DNA 芯片}

随着微电子技术的发展, 计算机芯片的集成度 不断增高, 对器件尺寸的要求也随之苛刻, 但是器件 工作原理和工艺技术限制了微型芯片的制造. DNA 折纸术作为新的纳米自组装方法, 在纳米器件制备 方面具有巨大的潜在应用价值. 目前国际上如 IBM, Intel 等大型公司也投人大量的精力进行这方面的研 究. 2009 年, IBM 与 Rothemund 等研究人员 ${ }^{[58]}$ 合作, 利用电子束刻蚀法和干法氧化刻蚀法在无机材料(如 二氧化硅和类金刚石等)的基底上刻蚀出折纸术结构 的结合位点, 将 DNA 分子当作建筑框架(或称为缩小 的电路板), 沉积并自组装成精密排列的图案, 使 DNA 折纸结构在无机半导体材料表面形成可控 有 序的排列(图 6). Rothemund 等人 ${ }^{[58]}$ 提出的 DNA 折纸 术与纳米光刻技术相结合的方法为微型纳米计算机 芯片的制备提供了可行性. Hung 等人 ${ }^{[59]}$ 将金纳米粒 子与 DNA 折纸术结构组装在一起, 利用电子束蚀 刻法在无机材料基底上刻蚀出 DNA 折纸术结构的吸
附位点, 然后将 DNA 折纸结构在基底上沉积, 得到 大面积的重复单元阵列结构. Hung 等人将“自上而 下”的电子束刻蚀法与“自下而上”的 DNA 折纸术有效 结合, 使 DNA 折纸纳米结构在纳米器件和纳米材料 等众多纳米领域具有巨大的发展潜力和广泛的应用前 景. 目前, DNA 折纸术制备的纳米芯片距离商业化产 品还存在一定的距离, 但是相信在将来, 通过 DNA 折 纸术制造的纳米芯片必将发挥令人瞩目的作用.

\section{2 构造 DNA 折纸术/纳米粒子复合功能组装体}

以 DNA 折纸结构为载体, 在纳米级别上精确排 布纳米颗粒 ${ }^{[60,61]}$, 通过调节纳米粒子的耦合相互作 用, 可控制复合纳米结构的光学、电子学性能. 研究 表明，当纳米金球的间距在 $10 \mathrm{~nm}$ 之内时，局部场增 强效果能得到明显的提高 ${ }^{[62]} .2010$ 年, Ding 等人 ${ }^{[63]}$ 利用 DNA 折纸模板的空间定位能力将不同尺寸的金 纳米粒子精确地组装到 DNA 折纸结构表面, 并准确 控制它们的间距在 $10 \mathrm{~nm}$ 之内, 如图 7(a)所示. 2011 年, Shen 等人 ${ }^{[64]}$ 以 DNA 纳米管为模板, 组装金纳米 粒子, 得到具有光学活性的金属手性结构 ${ }^{[65]}$. 研究 人员利用 M13 环状单链 DNA 与过量订书钉链和捕捉 链碱基互补配对得到在特定位点延伸出捕捉链的长 方形DNA 折纸结构, 通过 DNA 双链杂交组装由互补 DNA 序列修饰的金纳米颗粒, 形成两条平行排列的 金纳米链, 然后通过折叠链(folding strands)将长方形 DNA 折纸结构进行粘合卷曲, 得到 DNA 管状结构, 同时平行的二维金纳米链变成三维螺旋结构, 如图 7(b)所示. 这种三维螺旋金纳米粒子组装结构在纳米
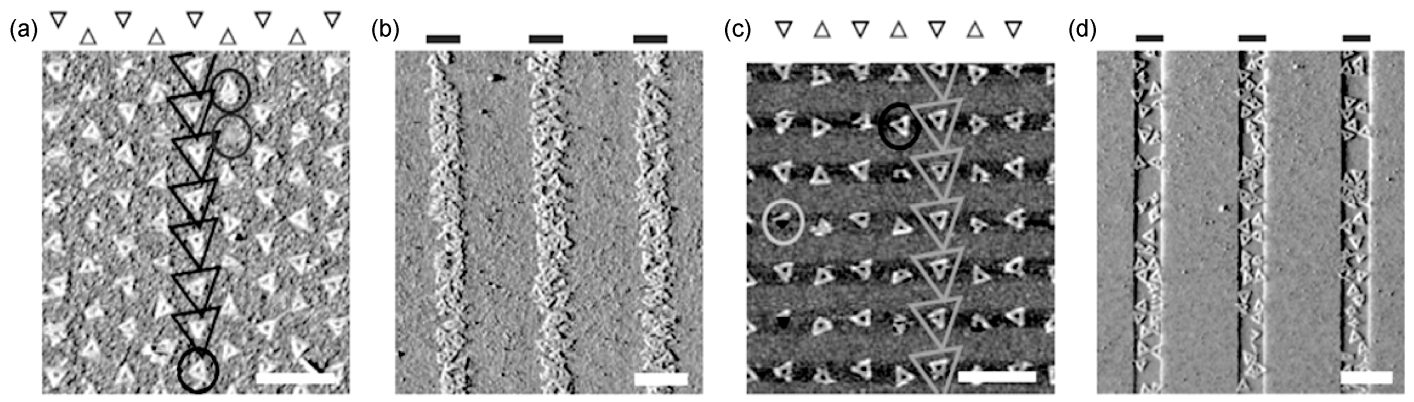

图 6 DNA 折纸术图形在无机材料表面排列位置与取向 ${ }^{[58]}$

(a) 三角形折纸术结构在三甲基硅烷/二氧化硅基底表面上 $110 \mathrm{~nm}$ 三角形模板排列的 AFM 照片; (b) 三角形折纸术结构在三甲基硅烷/ 二氧化硅基底表面上 $300 \mathrm{~nm}$ 线性模板通道紧密无序排列的 AFM 照片; (c) 三角形折纸术结构在类金刚石基底表面上 $110 \mathrm{~nm}$ 三角形模 型排列的 AFM 照片; (d) 三角形折纸术结构在类金刚石基底表面上 $200 \mathrm{~nm}$ 线性模板通道上排列的 AFM 图片. 所有标尺大小为 $500 \mathrm{~nm}$ 

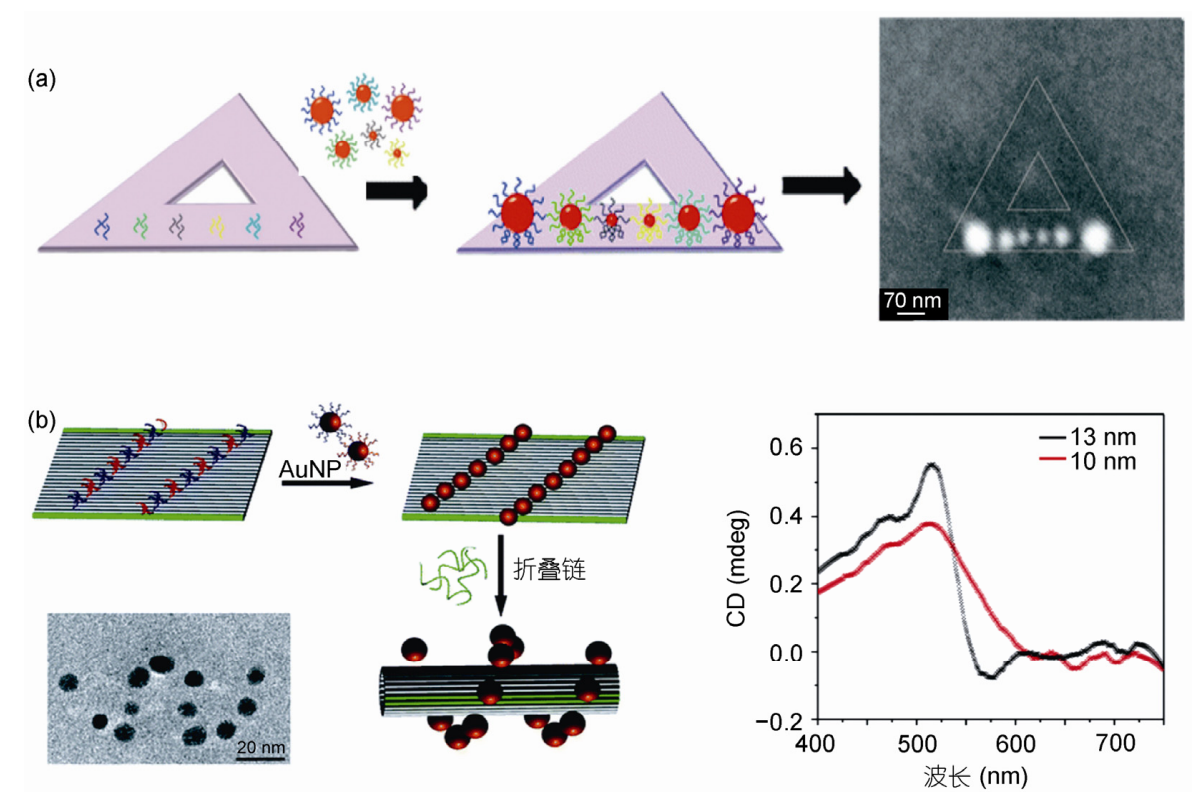

图 7 (a) 三角形折纸术结构与 6 个不同纳米金粒子复合组装结构的组装示意图和 SEM 照片 ${ }^{[63]}$; (b) 长方形 DNA 折纸结构 组装三维螺旋金纳米颗粒结构的示意图和三维金纳米螺旋结构的 TEM 照片与圆二色信号谱图 ${ }^{[64]}$

金的等离子体共振波长处具有明显的圆二色信号. DNA 折纸术与贵金属纳米粒子 ${ }^{[66]}$ 的复合, 可应用于 探测器、光波导管和纳米透镜等方面.

纳米金棒是典型的一维纳米材料, 由于其拉曼 增强效应和等离子体子共振效应 ${ }^{[67 \sim 69]}$ 比纳米金球更 为显著, 在很多领域具有较大的应用潜力. 但纳米金 棒的一维结构增加了组装过程的复杂性, 使纳米金 棒的组装难以得到准确的控制. 在之前的研究中, 纳 米金棒的排列组装是随机不可控的，限制了纳米金 棒的进一步研究 ${ }^{[70]} .2011$ 年, Pal 等人 ${ }^{[71]}$ 利用 DNA 折 纸术设计并合成特定位点伸出捕捉链(capture strands) 的三角形折纸结构，通过碱基互补配对，将修饰有颈 基化单链 DNA 的纳米金棒准确地连接到特定位置, 实现了纳米金棒的精确有序排列(图 8). 在三角形折 纸模板上, 通过对纳米金棒链接位点的改变, 实现了 纳米金棒在三角形折纸术模板上的不同排列, 并准 确控制金棒的间距和相互间的角度. 这将有助于调 节纳米粒子等离子体场的耦合程度, 改变等离子体 子共振效果, 提高局部场强, 获得独特的光学和电磁 学的性质.

与模块法组装 DNA 结构相比, DNA 折纸术无需 环状单链 DNA M13mp18 与互补订书钉链的严格计 量比, 而且订书钉链无需纯化, 操作更加简单. 过量
的订书钉链能降低错配的出现, 提高自组装的效率, 实现高品质 DNA 自组装结构的合成, 能够持续大量 高效地为其他功能纳米粒子的再次组装提供模板和 载体, 使得 DNA 折纸术在纳米领域具有非常大的研 究价值和潜在应用价值, 促进以 DNA 折纸术为基础 的纳米器件的研究. 但是 DNA 折纸术也存在一些缺 陷, DNA 折纸术纳米结构尺寸有局限性, 难以得到较 大的 DNA 折纸术结构 ${ }^{[72 ~ 75]}$; 易受温度 ${ }^{[76 ~ 79]}$ 等环境条 件的影响, DNA 折纸结构具有潜在的不稳定性. 受 M13 链长度的制约, DNA 折纸术组装得到的二维纳 米结构尺寸在 $100 \mathrm{~nm}$ 左右, 无法组装得到更大的结 构. 但是研究人员采用 DNA 折纸术与传统自组装方 法相结合的方法, 将 DNA 折纸术结构作为一个基本 的自组装结构单元, 通过分级组装得到更大的结构. 2010 年, Liu 等人 ${ }^{[75]}$ 利用 DNA 折纸术得到相互垂直 交叉的结构，再通过分级组装得到在两个方向上都 较大程度增长的二维结构. 2011 年, Zhao 等人 ${ }^{[80]}$ 提出 一种新的组装方法 superorigami(或称为 origami of origami). 他们利用 DNA 折纸术首先合成二维折纸 结构单元, 再通过桥接链 (bridge strand) 将纳米结构 单元进行二次组装, 得到较大的 DNA 折纸术结构. 2012 年, Yang 等人 ${ }^{[81]}$ 利用更大的双链 DNA 作为折纸 模版，通过调节组装条件得到了尺寸较大的 DNA 纳 
(a)

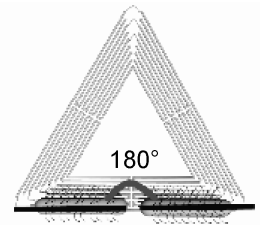

( i )

(b)

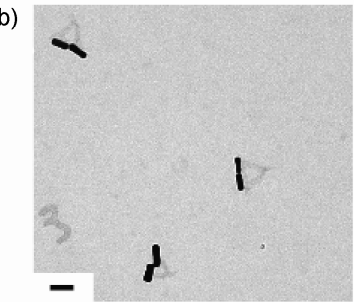

(c)

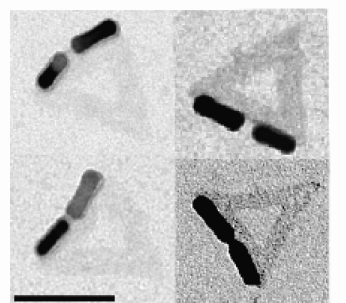

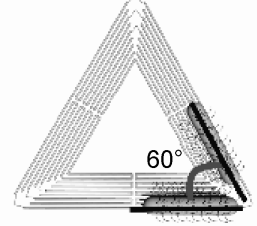

(ii)
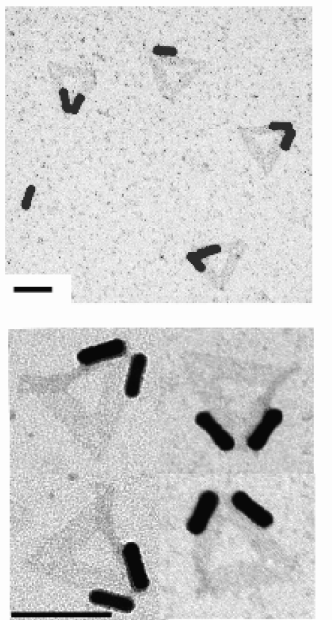

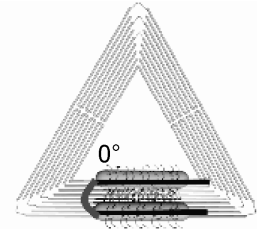

(iii)

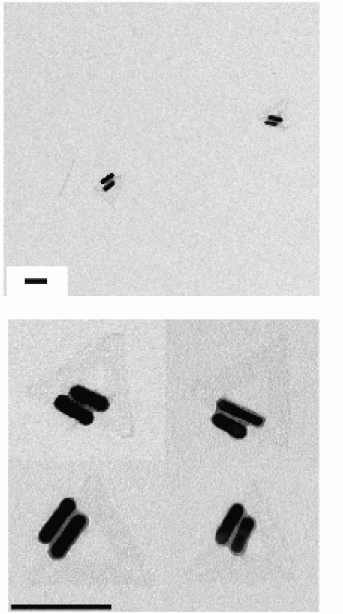

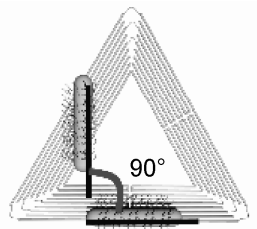

(iv)
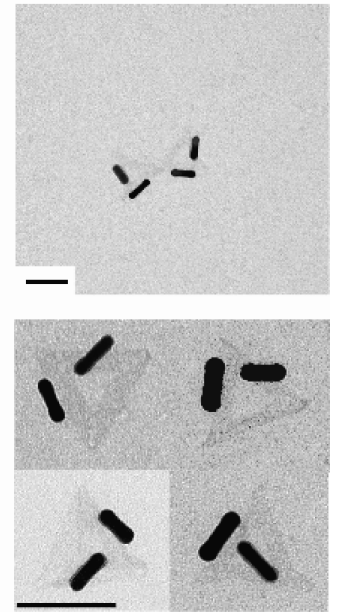

图 8 (a) (i) (iv)为不同金棒二聚体结构的图解示意图; (b) 每种金棒二聚体缩小的 TEM 照片, 样品用 $0.7 \%$ 的甲酸双氧铀 染色; (c) 典型的通过三角形折纸术结构准确组装纳米金棒的放大照片 ${ }^{[71]}$

所有的标尺示 $100 \mathrm{~nm}$

米结构. 较大尺寸 DNA 折纸结构的成功组装对 DNA 自组装领域及纳米器件的研究将具有显著的影响. DNA 折纸术得到的结构在一定条件下稳定性很好, 但是当环境改变时其结构可能被破坏, 如溶液的酸 碱性、溶液的自身性质 ${ }^{[82 \sim 84]}$ 、温度的改变等 ${ }^{[85 ~ 89]}$. 随 着研究的不断进行, DNA 折纸术结构的尺寸和稳定 性将会得到明显的改善. DNA 折纸术得到的纳米结 构可以作为单分子反应的平台, 也可作为功能纳米 粒子、生物分子、量子点组装的模板. 2012 年, Jiang 等人 ${ }^{[90]}$ 采用三角形或管状 DNA 折纸结构作为抗癌药 物载体, 显著降低了癌症细胞的耐药性. 这说明 DNA 折纸术结构作为药物的载体在相关疾病检测和 治疗方面发挥了特殊的优势.

\section{3 结论与展望}

DNA 折纸术通过严格的碱基互补配对规则进行 折叠, 能够实现纳米级别的精确组装, 为与其他功能 纳米材料的可控组装提供模板和载体. DNA 折纸术 为纳米结构可控图案化的制备提供了一条前景宽广 的道路, 为自下而上的组装技术提供了新方法. DNA 折纸术作为新兴的研究策略, 在构造二维和三维纳 米组装结构的研究中, 将对 DNA 芯片、纳米元件与 材料等领域的研究起到巨大的推进作用. 随着 DNA 折纸术研究的不断深人, 我们相信, DNA 折纸术在纳 米器件、疾病检测和治疗等诸多领域上的困难都将得 到逐步解决, 并推动相关领域学科的发展.

\section{参考文献}

1 Castro C E, Kilchherr F, Kim D N, et al. A primer to scaffolded DNA origami. Nat Methods, 2011, 8: 221-229

2 Lin C X, Liu Y, Yan H. Designer DNA nanoarchitectures. Biochemistry, 2009, 48: 1663-1674

3 Seeman N C. Nucleic acid junctions and lattices. J Theor Biol, 1982, 99: 237-247

4 Seeman N C, Lukeman P S. Nucleic acid nanostructures: Bottom-up control of geometry on the nanoscale. Rep Prog Phys, 2005, 68: $237-270$

5 Rothemund P W. Folding DNA to create nanoscale shapes and patterns. Nature, 2006, 440: 297-302

6 Seeman N C. Nanomaterials based on DNA. Annu Rev Biochem, 2010, 79: 65-87 
7 Aldaye F A, Palmer A L, Sleiman H F. Assembling materials with DNA as the guide. Science, 2008, 321: 1795-1799

8 Shih W M, Lin C X, Knitting complex weaves with DNA origami. Curr Opin Struct Biol, 2010, 20: 276-282

9 Nangreave J, Han D, Liu Y, et al. DNA Origami: A history and current perspective. Curr Opin Chem Biol, 2010, 14: 608-615

10 Keller A, Bald I, Rotaru A, et al. Probing electron-induced bond cleavage at the single-molecule level using DNA origami templates. ACS Nano, 2012, 6: 4392-4399

11 Acuna G P, Bucher M, Stein I H, et al. Distance dependence of single-fluorophore quenching by gold nanoparticles studied on DNA origami. ACS Nano, 2012, 6: 3189-3195

12 Bell N A W, Engst C R, Ablay M, et al. DNA origami nanopores. Nano Lett, 2012, 12: 512-517

13 Fu J L, Liu M H, Liu Y, et al. Interenzyme substrate diffusion for an enzyme cascade organized on spatially addressable DNA nanostructures. J Am Chem Soc, 2012, 134: 5516-5519

14 Subramani R, Juul S, Rotaru A, et al. A novel secondary DNA binding site in human topoisomerase I unravelled by using a 2D DNA origami platform. ACS Nano, 2010, 4: 5969-5977

15 Ke Y G, Sharma J, Liu M H, et al. Scaffolded DNA origami of a DNA tetrahedron molecular container. Nano Lett, 2009, 9: 2445-2447

16 Seeman N C. DNA in a material world. Nature, 2003, 421: 427-431

17 Winfree E, Liu F R, Seeman N C. Design and self-assemble of two-dimensional DNA crystals. Nature, 1998, 394: 539-544

18 Rothemund P W, Papadakis N, Winfree E. Algorithmic self-assembly of DNA Sierpinski triangles. PLoS Biol, 2004, 2: 2041-2053

19 Sa-Ardyen P, Vologodskii A V, Seeman N C. The flexibility of DNA double crossover molecules. Biophys J, 2003, 84: 3829-3837

20 Fu T J, Seeman N C. DNA double-crossover molecules. Biochemistry, 1993, 32: 3211-3220

21 Li X J, Yang X P, Qi J, et al. Antiparallel DNA double crossover molecules as components for nanoconstruction. J Am Chem Soc, 1996, 118: 6131-6140

22 LaBean T H, Yan H, Kopatsch J, et al. Construction, analysis, ligation, and self-assembly of DNA triple crossover complexes. J Am Chem Soc, 2000, 122: 1848-1860

23 Yan H, Park S H, Finkelstein G, et al. DNA-templated self-assembly of protein arrays and highly conductive nanowires. Science, 2003, 301: 1882-1884

24 He Y, Chen Y, Liu H P, et al. Self-assembly of hexagonal DNA two-dimensional (2D) arrays. J Am Chem Soc, 2005, 127: 12202-12203

He Y, Ye T, Su M, et al. Hierarchical self-assembly of DNA into symmetric supramolecular polyhedral. Nature, 2008, 452: 198-201

Zhang F, Nangreave J, Liu Y, et al. Reconfigurable DNA origami to generate quasifractal patterns. Nano Lett, 2012, 12: 3290-3295

Wei B R, Dai M J, Yin P. Complex shapes self-assembled from single-stranded DNA tiles. Nature, 2012, 485: 623-626

34 Ke Y G, Voigt N V, Gothelf K V, et al. Multilayer DNA origami packed on hexagonal and hybrid lattices. J Am Chem Soc, 2012, 134: 1770-1774

37 Pilo-Pais M, Goldberg S, Samano E, et al. Connecting the nanodots: Programmable nanofabrication of fused metal shapes on DNA templates. Nano Lett, 2011, 11: 3489-3492

38 Maye M M, Cuisinier M, Nykypanchuk D, et al. High throughput assembly of DNA-linked nanoparticle clusters. Nat Mater, 2009, 8: 388-391

39 Cheng W L, Campolongo M J, Cha J J, et al. Free-standing nanoparticle superlattice sheets controlled by DNA. Nat Mater, 2009, 8: 519-525

40 Tian J, Ma K, Saaem I. Advancing high-throughput gene synthesis technology. Mol BioSyst, 2009, 5: 714-722

41 Mirkin C A, Letsinger R L, Mucic R C, et al. A DNA-based method for rationally assembling nanoparticles into macroscopic materials. Nature, 1996, 382: 607-609

42 Zhang J P, Liu Y, Ke Y G, et al. Periodic square-like gold nanoparticle arrays templated by self-assembled 2D DNA nanogrids on a surface. Nano Lett, 2006, 6: 248-251

43 Sharma J, Chhabra R, Liu Y, et al. DNA templated self-assembly of two-dimensional and periodical gold nanoparticle arrays. Angew Chem Int Ed, 2006, 45: 730-735 
44 Zheng J W, Constantinou P E, Micheel C, et al. Two-dimensional nanoparticle arrays show the organizational power of robust DNA motifs. Nano Lett, 2006, 6: 1502-1504

45 Sharma J, Chhabra R, Cheng A C, et al. Control of self-assembly of DNA tubules through integration of gold nanoparticles. Science, 2009, 323: $112-116$

46 Zhao Z, Liu Y, Yan H. Encapsulation of gold nanoparticles in a DNA origami cage. Angew Chem Int Ed, 2011, 50: 2041-2044

47 Pal S, Deng Z T, Ding B Q, et al. DNA origami directed self-assembly of discrete silver nanoparticle architectures. Angew Chem Int Ed, 2010, 49: 2760-2764

48 Stein I H, Steinhauter C, Tinnefeld P. Single-molecule four-color FRET visualizes energy-transfer paths on DNA origami. J Am Chem Soc, 2011, 133: 4193-4195

49 Cohen J D, Sadowski J P, Dervan P B. Addressing single molecules on DNA nanostructures. Angew Chem Int Ed, 2007, 119: 7956-7959

50 Erben C M, Goodman R P, Turberfield A J. Single-molecule protein encapsulation in a rigid DNA cage. Angew Chem Int Ed, 2006, 118: 7574-7577

51 Chhabra R, Sharma J, Ke Y G, et al. Spatially addressable multiprotein nanoarrays templated by aptamer-tagged DNA nanoarchitectures. J Am Chem Soc, 2007, 129: 10304-10305

52 Saccà B, Meyer R, Erkelenz M, et al. Orthogonal protein decoration of DNA origami. Angew Chem Int Ed, 2010, 49: 9378-9383

53 Williams B A R, Lund K, Liu Y, et al. Self-assembled peptide nanoarrays: An approach to studying protein-protein interactions. Angew Chem Int Ed, 2007, 119: 3111-3114

54 Maune H T, Han S P, Barish R D, et al. Self-assembly of carbon nanotubes into two-dimensional geometries using DNA origami templates. Nat Nanotech, 2010, 5: 61-66

55 Ko S H, Gallatin G M, Liddle J A. Nanomanufacturing with DNA origami: Factors affecting the kinetics and yield of quantum dot binding. Adv Funct Mater, 2012, 22: 1015-1023

56 Sharma J, Ke Y G, Lin C X, et al. DNA-tile-directed self-assembly of quantum dots into two-dimensional nanopatterns. Angew Chem Int Ed, 2008, 47: 5157-5159

57 Bui H, Onodera C, Kidwell C, et al. Programmable periodicity of quantum dot arrays with DNA origami nanotubes. Nano Lett, 2010, 10: 3367-3372

58 Kershner R J, Bozano L D, Micheel C M, et al. Placement and orientation of individual DNA shapes on lithographically patterned surfaces. Nat Nanotech, 2009, 4: 557-561

59 Hung A M, Cha J N. Templated assembly of DNA origami gold nanoparticle arrays on lithographically patterned surfaces. Methods Mol Biol, 2011, 749: 187-197

60 Daniel M C, Astruc D. Gold nanoparticles: Assembly, supramolecular chemistry, quantum-size-related properties, and applications toward biology, catalysis, and nanotechnology. Chem Rev, 2004, 104: 293-346

61 Giljohann D A, Seferos D S, Daniel W L, et al. Gold nanoparticles for biology and medicine. Angew Chem Int Ed, 2010, 49: 3280-3294

62 Li K R, Stockman M I, Bergman D J. Self-similar chain of metal nanospheres as an efficient nanolens. Phys Rev Lett, 2003, 91: 227402

63 Ding B Q, Deng Z T, Yan H, et al. Gold nanoparticle self-similar chain structure organized by DNA origami. J Am Chem Soc, 2010, 132: 3248-3249

64 Shen X B, Song C, Wang J Y, et al. Rolling up gold nanoparticle-dressed DNA origami into three-dimensional plasmonic chiral nanostructures. J Am Chem Soc, 2012, 134: 146-149

65 Kuzyk A, Schreiber R, Fan Z Y, et al. DNA-based self-assembly of chiral plasmonic nanostructures with tailored optical response. Nature, 2012, 483: 311-314

66 Ding B Q, Wu H, Yan H, et al. Interconnecting gold islands with DNA origami nanotubes. Nano Lett, 2010, 10: 5065-5069

67 Fu Y, Zhang J, Joseph R, et al. Plasmon-enhanced fluorescence from single fluorophores end-linked to gold nanorods. J Am Chem Soc, 2010, 132: 5540-5541

68 Funston A M, Novo C, Davis T J, et al. Plasmon coupling of gold nanorods at short distances and in different geometries. Nano Lett, 2009, 9: $1651-1658$

69 Woo K C, Shao L, Chen H J, et al. Universal scaling and fano resonance in the plasmon coupling between gold nanorods. ACS Nano, 2011, 5: 5976-5986

70 Li Y, Qian F, Lieber C M, et al. Nanowire electronic and optoelectronic devices. Mater Today, 2006, 9: 18-27

71 Pal S, Deng Z T, Wang H N, et al. DNA directed self-assembly of anisotropic plasmonic nanostructures. J Am Chem Soc, 2011, 133: 17606-17609

72 Li Z, Liu M H, Wang L, et al. Molecular behavior of DNA origami in higher-order self-assembly. J Am Chem Soc, 2010, 132: $13545-13552$ 
73 Majumder U, Rangnekar A, Gothelf K V, et al. Design and construction of double-decker tile as a route to three-dimensional periodic assembly of DNA. J Am Chem Soc, 2011, 133: 3843-3845

74 Zhao Z, Yan H, Liu Y. A route to scale up DNA origami using DNA tiles as folding staples. Angew Chem Int Ed, 2010, 122: 1456-1459

75 Liu W, Zhong H, Wang R, et al. Crystalline two-dimensional DNA-origami arrays. Angew Chem Int Ed, 2011, 123: 278-281

76 Song J, Arbona J M, Zhang Z, et al. Direct visualization of transient thermal response of a DNA origami. J Am Chem Soc, 2012, 134: 9844-9847

77 Li Z, Wang L, Yan H, et al. Effect of DNA hairpin loops on the twist of planar DNA origami tiles. Langmuir, 2012, 28: 1959-1965

78 Saccà B, Meyer M, Feldkamp U, et al. High-throughput, real-time monitoring of the self-assembly of DNA nanostructures by FRET spectroscopy. Angew Chem Int Ed, 2008, 47: 2135-2137

79 Nangreave J, Yan H, Liu Y. Studies of thermal stability of multivalent DNA hybridization in a nanostructured system. Biophys J, 2009, 97 : 563-571

80 Zhao Z, Liu Y, Yan H. Organizing DNA origami tiles into larger structures using preformed scaffold frames. Nano Lett, 2011, 11: 2997-3002

81 Yang Y, Han D R, Nangreave J, et al. DNA origami with double-stranded DNA as a unified scaffold. ACS Nano, 2012, 6: 8209-8215

82 Mei Q, Wei X X, Su F Y, et al. Stability of DNA origami nanoarrays in cell lysate. Nano Lett, 2011, 11: 1477-1482

83 Schüller V J, Heidegger S, Sandholzer N, et al. Cellular immunostimulation by CpG-sequence-coated DNA origami structures. ACS Nano, 2011, 5: 9696-9702

84 Woo S, Rothemund P W K. Programmable molecular recognition based on the geometry of DNA nanostructures. Nat Chem, 2011, 3: $620-627$

85 Alloyeaua D, Ding B Q, Ramasse Q, et al. Direct imaging and chemical analysis of unstained DNA origami performed with a transmission electron microscope. Chem Commun, 2011, 47: 9375-9377

86 Rajendran A, Endo M, Katsuda Y, et al. Photo-cross-linking-assisted thermal stability of DNA origami structures and its application for higher-temperature self-assembly. J Am Chem Soc, 2011, 133: 14488-14491

87 Yin P, Hariadi R F, Sahu S, et al. Programming DNA tube circumferences. Science, 2008, 321: 824-826

88 Liu H P, Chen Y, He Y, et al. Approaching the limit: Can one DNA oligonucleotide assemble into large nanostructures. Angew Chem Int Ed, 2006, 45: 1942-1945

89 Endo M, Sugita T, Rajendran A, et al. Two-dimensional DNA origami assemblies using a four-way connector. Chem Commun, 2011, 47: 3213-3215

90 Jiang Q, Song C, Nangreave J, et al. DNA origami as a carrier for circumvention of drug resistance. J Am Chem Soc, 2012, 134: $13396-13403$

\title{
Recent progress in DNA origami
}

\author{
SHI DangWei ${ }^{1,2}$, WANG ZhenGang ${ }^{2}$, XU JingKun ${ }^{1} \&$ DING BaoQuan ${ }^{2}$ \\ ${ }^{1}$ Jiangxi Key Laboratory of Organic Chemistry, Jiangxi Science and Technology Normal University, Nanchang 330013, China; \\ ${ }^{2}$ National Center for Nanoscience and Technology, Beijing 100190, China
}

As a novel self-assembly method developed in recent years, DNA origami is one of the greatest progress in the field of DNA nanotechnology and DNA self-assembly. Different from traditional DNA self-assembly, DNA origami, on the basis of the hybridization of a long circular genomic single stranded DNA with a group of staple strands, can be used to construct two- or threedimensional sophisticated shapes at the nanoscale. Moreover, the nanostructures by DNA origami are more predictable, precise, controllable and efficient. The merits also include relatively low requirements for the experimental conditions and operation skills. A variety of functional nanoparticles can be assembled onto the DNA origami nanoscaffolds, to obtain complicate nanodevices with special functions. Therefore, DNA origami has shown great potential in nanotechnology. This review describes the progress of DNA origami in the assembly of diverse DNA nanostructures and the prospect of DNA origami in future.

\section{DNA self-assembly, DNA origami, nanodevice, template, controllable, efficient}

